\title{
Pengembangan Media Kotak Cahaya Pelajaran IPA Materi Sifat-Sifat Cahaya
}

\author{
Mariatus Sholiha ${ }^{1}$, Badrud Tamam², Fatimatul Munawaroh ${ }^{3}$ \\ 1,2,3Fakultas IImu Pendidikan, Universitas Trunojoyo Madura \\ 3fatimphysics@gmail.com
}

\begin{abstract}
ABSTRAK
Media pembelajaran merupakan salah satu faktor penting dalam keberhasilan proses pembelajaran. Tujuan penelitian ini adalah untuk mengetahui efektifitas, efisien, dan daya tarik media pembelajaran Kotak cahaya pada materi sifat-sifat cahaya. Penelitian ini menggunakan model 4D yang terdiri dari 4 tahapan define, design, development dan dessiminate. Namun peneliti memodifikasi model 4D menjadi $3 D$, yakni tahap disseminate dalam penelitian ini tidak dilakukan karena keterbatasan waktu, biaya, dan tenaga. Instrumen dan media pembelajaran ini telah divalidasi oleh beberapa ahli yaitu ahli bahasa, ahli materi dan ahli media. Terdapat 3 uji coba penelitian yaitu uji coba perorangan, uji coba kelompok kecil, dan uji coba kelompok besar. Berdasarkan hasil penelitian yang dilakukan, diperoleh hasil bahwa persentase kelayakan media pembelajaran Kotak cahaya menurut ahli bahasa adalah 99,4\% (sangat layak), ahli materi 90\% (sangat layak), dan ahli media 86,9\% (sangat layak). Efektivitas media pembelajaran Kotak cahaya diukur dari segi proses yang didapat dari tes hasil belajar yaitu pada uji perorangan $100 \%$ (sangat efektif), uji kelompok kecil 100\% (sangat efektif), dan uji kelompok besar 95,4\% (sangat efektif). Efisiensi media pembelajaran Kotak cahaya yang diperoleh dari hasil validasi ahli media mendapatkan persentase $87,5 \%$. Sedangkan kemenarikan media pembelajaran Kotak cahaya diukur menggunakan angket siswa dengan persentase uji perorangan 98,3\% (sangat menarik), kelompok kecil 94,6\% (sangat menarik), dan kelompok besar 96,6\% (sangat menarik). Berdasarkan hasil dari validasi ahli dan uji coba, media kotak cahaya layak untuk digunakan dalam pembelajaran IPA.
\end{abstract}

Kata Kunci: Media Pembelajaran, kotak cahaya, materi Sifat-sifat Cahaya 


\section{PENDAHULUAN}

IImu Pengetahuan Alam atau yang biasa disebut sains merupakan cabang pengetahuan yang berawal dari fenomena alam yang terjadi dalam kehidupan sehari-hari. Hal ini diperkuat oleh Julianto (2011:1) yang mendefinisikan IPA sebagai sekumpulan pengetahuan tentang objek dan fenomena alam. Objek dan fenomena alam tersebut diperoleh dari hasil pemikiran, dan penemuan para ilmuwan yang ahli dalam bereksprimen dengan metode ilmiah. Secara umum, IPA merupakan suatu mata pelajaran dimana didalamnya terdapat pengetahuan, observasi, dan eksperimen untuk mengetahui ilmuilmu tersebut. Rustman (2010 :1.2) memandang IPA atau sains sebagai suatu proses yang menghasilkan pengetahuan. Proses tersebut bergantung pada proses observasi yang cermat terhadap fenomena dan pada teori-teori temuan untuk memaknai hasil observasi tersebut.

Berdasarkan pengertian IPA diatas, maka sebagai seorang guru. Hendaklah merancang dan melaksanakan pembelajaran IPA yang memungkinkan siswa mampu belajar aktif dan menumbuhkan kesan bermakna dari pembelajaran yang sudah dilakukan. Selain itu juga menciptakan suasana pembelajaran yang menarik perhatian siswa sehingga materi pelajaran dapat diingat oleh siswa.

Proses belajar mengajar pada hakikatnya adalah proses komunikasi. Yaitu proses penyampaian pesan dari sumber pesan melalui media tertentu ke penerima pesan. Pesan, sumber pesan, media, dan penerima pesan adalah komponen-komponen proses komunikasi. Dalam kegiatan pembelajaran pesan yang akan dikomunikasikan adalah isi ajaran atau materi yang ditetapkan berdasarkan kurikulum yang berlaku. Berbagai macam sumber pesan diantaranya pengajar, peserta didik, orang lain, penulis buku, produser media dan sebagainya.

Media pembelajaran juga dapat dijadikan sebagai sumber pesan. Sumber yang dapat digunakan dalam kegiatan pembelajaran untuk mempermudah pengajar dalam menyampaikan pesan. Dalam penyampaian konsep materi yang dilakukan oleh guru kebanyakan masih menggunakan metode konvensional. Guru biasanya mengajar tanpa menggunakan metode yang menarik, atau menggunakan alat bantu pembelajaran. Selain itu, masih banyak sekolah-sekolah yang belum mempunyai alat peraga KIT IPA yang diberikan oleh pemerintah. Sehingga membutuhkan kreativitas masingmasing guru dalam menyampaikan pesan kepada siswa agar materi IPA dapat tersampaikan dengan jelas.

Hal ini dibenarkan oleh salah satu guru di SDN Bancaran 04 yang bernama ibu Siska wali kelas 5. Melalui wawancara tidak terstruktur pada hari Selasa tanggal 3 November 2015. Ibu Siska menyatakan bahwa dalam pembelajarannya ia jarang sekali menggunakan alat bantu berupa media pembelajaran. Hal itu dikarenakan dalam menyiapkan media pembelajaran membutuhkan waktu dalam membuatnya dan alokasi waktu yang sangat kurang untuk mempersiapkan alat bantu tersebut.

Dalam pembelajaran IPA, konsep materi hendaklah disampaikan dengan cara mengenalkan terlebih dahulu masalah dengan lingkungan siswa dan juga kedaan nyata disekitar siswa. Salah satu materi pelajaran IPA yang sangat erat kaitannya dengan lingkungan dan kehidupan nyata siswa adalah konsep sifat - sifat cahaya, konsep tersebut hendaknya disampaiakan oleh guru dengan cara semenarik mungkin karena materi tersebut sangat banyak. Konsep materi sifat-sifat cahaya tidak dapat 
disampaikan secara verbalisme, tetapi diajarkan kepada siswa dengan cara praktek dan observasi langsung hal ini untuk mempermudah siswa memahami konsep sifat - sifat cahaya. Setelah melakukan praktek maka guru memberikan penjelasan kepada siswa dengan mengaitkannya dengan kehidupan sehari-hari siswa. Maka dari itu, untuk mempermudah dalam menyampaikan pesan hendaknya seorang guru haruslah menggunakan media pembelajaran dalam setiap pembelajarannya didalam kelas. Pemilihan pembuatan media pembelajaran memiliki banyak jenisnya ada visual, audio, dan audio-visual. Guru tinggal menyesuaikan tujuan pembelajaran dengan karakteristik siswa dan media pembelajaran yang akan digunakan saja. Peran media pembelajaran tidak semata hanya sebagai alat bantu menyampaikan pesan kepada siswa. Tetapi diharapkan mampu memberikan kesan menarik perhatian siswa untuk memahami pelajaran serta juga agar siswa mudah mengingat materi yang disampaikan.

Media pembelajaran adalah segala sesuatu yang dapat menyampaikan pesan dan mendorong terjadinya proses belajar pada siswa. Pemahaman isi materi dalam sebuah pembelajaran dapat dengan mudah dipahami dan diterima oleh siswa dengan menggunakan bantuan media pembelajaran. Alat bantu yang dipakai adalah alat bantu visual, misalnya gambar, model, objek, dan alat-alat lain yang dapat memberikan pengalaman konkret, motivasi belajar serta mempertinggi daya serap dan retensi belajar siswa.

Oleh sebab itu, media pembelajaran hendaknya digunakan dalam kegiatan pembelajaran. Dengan menggunakan media pembelajaran siswa dapat dengan mudah memahami dan mengerti materi pelajaran yang disampaikan. Juga dapat menarik perhatian siswa dalam belajar sehingga siswa menjadi belajar lebih aktif. Sebagaimana dikatakan oleh Azhar (2007 : 91), bahwa media memegang peran yang sangat penting dalam proses belajar. Sudjana (2010:2) juga berpendapat bahwa media pengajaran dapat mempertinggi proses belajar siswa dalam pengajaran yang pada gilirannya diharapkan dapat mempertinggi hasil belajar yang dicapainya.

Media pembelajaran dapat mengatasi batas ruang kelas, terutama untuk menyajikan bahan belajar yang sulit dipahami secara langsung oleh peserta didik. Melalui media pembelajaran, guru dapat menyajikan bahan pelajaran yang bersifat abstrak menjadi konkret sehingga mudah dipahami dan dapat menghilangkan verbalisme. Sehingga media pembelajaran merupakan sumber belajar atau alat bantu pembelajaran untuk meningkatkan efektifitas dan efisiensi dalam mencapai tujuan pembelajaran (Wina, 2011:170).

SDN Bancaran 4 Bangkalan merupakan sekolah negeri yang masih menerapkan kurikulum KTSP. SDN Bancaran 4 ini terletak bersebelahan dengan SDN Bancaran 2 Bangkalan, yang sama-sama berada disamping pasar Bancaran. Berdasarkan observasi lapangan yang telah dilakukan. Kondisi siswa kelas V SDN Bancaran 4 saat proses pembelajaran IPA materi sifatsifat cahaya terlihat sangat pasif, siswa tampak hanya duduk rapi mendengarkan penjelasan dari guru, dan tidak begitu banyak siswa yang bertanya.

Berdasarkan wawancara dengan wali kelas 5 SDN Bancaran 4 mengatakan bahwa siswa di SDN Bancaran 04 masih mengalami kesulitan belajar IPA. Terbukti dari hasil belajar siswa yang rata-rata memiliki nilai dibawah KKM yang sudah ditentukan oleh pihak sekolah yaitu 70 . Namun tidak semua siswa yang 
mendapatkan nilai dibawah KKM ada 4 siswa yang mendapatkan nilai diatas $\mathrm{KKM}, 12$ siswa mendapat nilai sama dengan KKM. Sedangkan 20 siswa lainnya mendapatkan nilai dibawah KKM. Hal ini dikarenakan guru hanya menggunakan buku paket sebagai sumber belajar dan banyaknya materi yang harus dimengerti siswa dalam waktu singkat. Selain itu, pihak sekolah belum mempunyai alat peraga KIT IPA yang diberikan oleh pemerintah.

Dengan demikian perlu dikembangkan media pembelajaran untuk membantu dalam kegiatan belajar mengajar dikelas. Sehingga dengan penggunaan media pembelajaran hasil belajar siswa dapat meningkat. Pembelajaran menjadi menarik, serta siswa menjadi lebih mudah dalam memahami dan menguasai materi pelajaran IPA. Begitu banyak sekali manfaat dari penggunaan media pembelajaran didalam kelas. Tidak hanya untuk mempermudah menyampaikan materi pelajaran semata, tetapi juga dapat meningkatkan hasil belajar siswa.

Hal ini terlihat dari penelitian yang dilakukan oleh Heriyanto (2014) yang menyatakan bahwa media pembelajaran memiliki pengaruh yang positif terhadap hasil belajar siswa, tidak hanya pada mata pelajaran IPA tetapi pada semua mata pelajaran. Berdasarkan penelitiannya media pembelajaran berupa benda konkrit dapat meningkatkan hasil belajar siswa IPA pada kelas 5 Sekolah Dasar sebesar $41,6 \%$. Sedangkan menurut Wardoyo (2015) diketahui bahwa media pembelajaran berbasis video animasi sangat efektif digunakan dalam pembelajaran di SMK Negeri 1 Purworejo. Berdasarkan validasi ahli media sebesar (82,5\%) termasuk kriteria "sangat layak" untuk digunakan. Hasil uji coba media pembelajaran yang dihasilkan mampu meningkatkan minat belajar siswa sebesar $(20,70 \%)$ setelah menggunakan media.

\begin{abstract}
Dari permasalahan yang terjadi diatas, maka peneliti ingin mengembangkan suatu media pembelajaran mengenai pelajaran IPA yaitu materi Sifat-sifat Cahaya. Maka dari itu penelitian ini mengambil judul "Pengembangan Media Kotak Cahaya Pada Pelajaran IPA Materi Sifat - sifat Cahaya kelas 5 SDN Bancaran 04 Bangkalan".
\end{abstract}

\section{METODE PENELITIAN}

Jenis penelitian yang digunakan dalam penelitian ini adalah penelitian research and development atau yang biasa disebut dengan penelitian pengembangan. Dalam penelitian ini mengembangkan suatu perangkat pembelajaran yaitu media pembelajaran kotak cahaya. Untuk membantu mempermudah menerangkan materi sifat-sifat cahaya pada siswa kelas 5 sekolah dasar.

Dalam menciptakan media kotak cahaya ini menggunakan model 4D yang termodifikasi, karena model tersebut dalam setiap langkahlangkahnya terdapat langkah revisi yang dapat membantu memperbaiki media yang diciptakan. Selain itu juga tidak perlu mengulang langkah sebelumnya setelah melakukan revisi, sehingga dalam pelaksanaannya dirasakan lebih mudah dan dapat mempersingkat waktu penelitian. Adapun langkah-langkah yang harus dilakukan dalam melaksanakan penelitian pengembangan model 4D ini adalah sebagai berikut : (1) tahap pendefinisian/define, (2) tahap perancangan/design, (3) tahap pengembangan/develop, (4) tahap pendiseminasian/disseminate.

Setiap tahapan masih terdapat beberapa langkah dalam setiap tahapnya. Sedangkan pada penelitian ini peneliti memodifikasi model 4D karena peneliti memiliki keterbatasan waktu, tenaga dam biaya maka penelitian ini dilakukan hanya sampai pada tahap ke 
Tabel 1. Kriteria Validasi Ahli dan Pengguna

\begin{tabular}{llll}
\hline No & Pencapaian Nilai & $\begin{array}{l}\text { Kategori } \\
\text { Validitas }\end{array}$ & Keterangan \\
\hline 1 & $81 \%<x \leq 100 \%$ & Sangat Valid & Sangat baik digunakan \\
2 & $62 \%<x \leq 81 \%$ & Valid & Boleh digunakan dengan revisi kecil \\
3 & $43 \%<x \leq 62 \%$ & Cukup valid & Boleh digunakan dengan revisi besar \\
4 & $24 \%<x \leq 43 \%$ & Kurang valid & Tidak boleh digunakan \\
5 & $5 \%<x \leq 24 \%$ & Tidak valid & Tidak boleh digunakan \\
\hline
\end{tabular}

Sumber : Modifikasi dari kriteria Akbar (2013:82)

Tabel 2. Kriteria Kemenarikan Media Pembelajaran

\begin{tabular}{lll}
\hline No & Interval & \multicolumn{1}{c}{ Kemenarikan } \\
\hline 1 & $81 \%<x \leq 100 \%$ & Sangat Menarik \\
2 & $62 \%<x \leq 81 \%$ & Menarik \\
3 & $43 \%<x \leq 62 \%$ & Cukup Menarik \\
4 & $24 \%<x \leq 43 \%$ & Kurang Menarik \\
5 & $5 \%<x \leq 24 \%$ & Tidak Menarik \\
\hline & & Sumber : Modifikasi dari kriteria Akbar (2013:78)
\end{tabular}

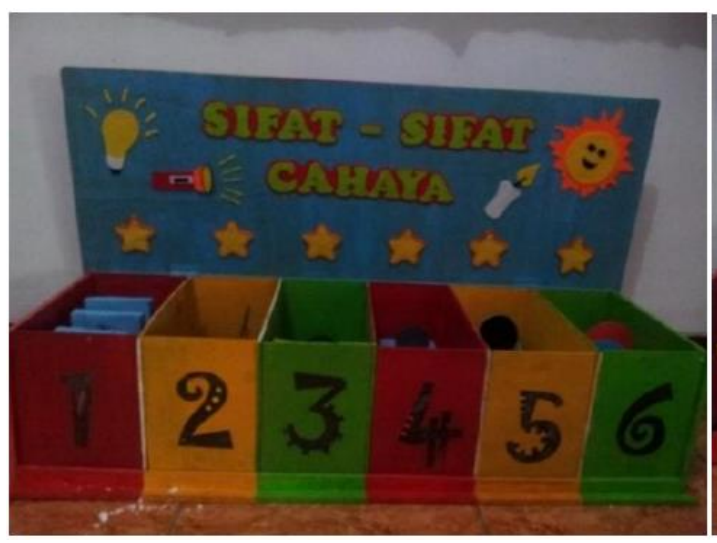

(a) Media kotak cahaya

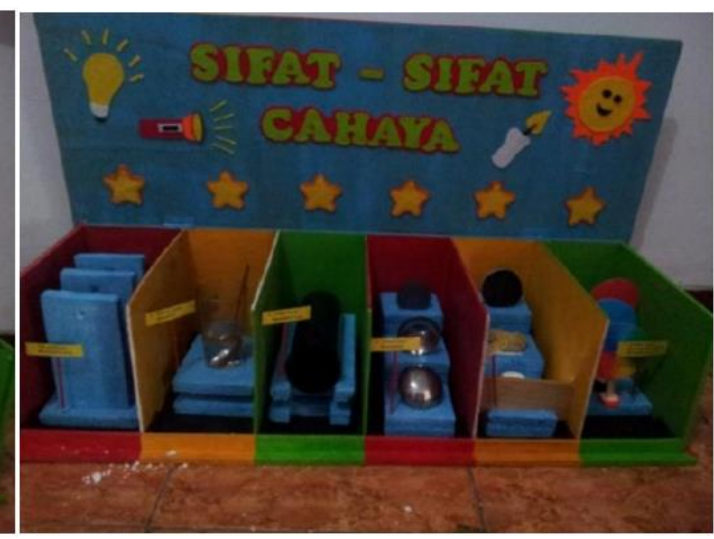

(b) Media kotak cahaya setelah pintu-pintu dibuka

Gambar 1. Produk media kotak cahaya yang dikembangkan

tiga yaitu pada tahap develop (pengembangan).

Teknik analisis data dalam penelitian ini untuk mengolah data dari hasil tinjauan para ahli, hasil uji coba perorangan, uji coba kelompok kecil, dan juga uji coba kelompok besar maka digunakanlah analisis statistik deskriptif.

Data dari angket yang diberikan kepada seluruh ahli, kemudian diolah dengan menggunakan rumus sebagai berikut : (Sa'dun Akbar, 2015:82)
Skor $=\frac{T S e}{T S h} \times 100 \%$

Keterangan: TSe $=$ total skor peroleh

$$
\text { TSh }=\text { total skor maksimal }
$$

Sedangkan hasil angket dari uji coba dianalisis untuk mengetahui kemenarikan menggunakan prosentase kemenarikan seperti pada tabel 2:

Persentase Kemenarikan = $\frac{\text { skor yang diperoleh }}{\text { Skor Maksimal }} \times 100 \%$ 


\section{HASIL DAN PEMBAHASAN}

dikembangkan

Media Kotak Cahaya yang

Gambar 1 adalah hasil media kotak cahaya yang dikembangkan.

\section{Hasil Pengujian Ahli Materi}

Media kotak cahaya divalidasikan oleh dosen program studi pendidikan IPA FIP yang ahli dibidang fisika yaitu Bapak Mochammad Ahied, S.Si.,M.Si. Hasil Penilaian ahli materi dapat dilihat pada tabel 3. Setelah dilakukan analisis data menggunakan persamaan (1) diperoleh presentase $90 \%$. Berdasarkan tabel 1 dapat dilihat bahwa untuk persentase $90 \%$ adalah sangat valid sehingga media yang dikembangkan sangat baik digunakan.
Ramansyah, S.Pd., M.Pd.. Hasil Penilaian ahli media dapat dilihat pada tabel 4. Setelah dilakukan analisis data menggunakan persamaan (1) diperoleh presentase $86,9 \%$. Berdasarkan tabel 1 dapat dilihat bahwa untuk persentase $86,9 \%$ adalah valid sehingga media yang dikembangkan baik digunakan.

\section{Hasil Pengujian Ahli Bahasa}

Media kotak cahaya dilengkapi dengan petunjuk penggunaan media, petunjuk ini divalidasikan ke dosen ahli bahasa oleh ibu Ummi Fitrah S.Pd., M.Pd. selaku ahli bahasa. Hasil Penilaian ahli media dapat dilihat pada tabel 5 . Setelah dilakukan analisis data menggunakan persamaan (1) diperoleh

Tabel 3 Hasil Validasi Ahli Materi

\begin{tabular}{|c|l|c|}
\hline No & \multicolumn{1}{|c|}{ Kriteria } & Skor \\
\hline 1 & Kesesuain media kotak cahaya dengan materi sifat-sifat cahaya & 4 \\
\hline 2 & $\begin{array}{l}\text { Pemahaman materi sifat-sifat cahaya oleh siswa menggunakan } \\
\text { media kotak cahaya }\end{array}$ & 3 \\
\hline 3 & $\begin{array}{l}\text { Kemudahan siswa dalam memahami materi menggunakan media } \\
\text { kotak cahaya }\end{array}$ & 4 \\
\hline 4 & $\begin{array}{l}\text { Ketepatan perumusan tujuan pembelajaran dalam media kotak } \\
\text { cahaya }\end{array}$ & 3 \\
\hline 5 & $\begin{array}{l}\text { Pembahasan atau kelengkapan sifat-sifat cahaya pada media kotak } \\
\text { cahaya }\end{array}$ & 3 \\
\hline 6 & Sumber cahaya pada media kotak cahaya & 3 \\
\hline 7 & Kejelasan uraian materi dalam media kotak cahaya & 4 \\
\hline 8 & $\begin{array}{l}\text { Ketepatan dan kebenaran media kotak cahaya terhadap materi yang } \\
\text { ada }\end{array}$ & 4 \\
\hline 9 & $\begin{array}{l}\text { Efektifitas media kotak cahaya dalam menyampaikan materi kepada } \\
\text { siswa }\end{array}$ & 4 \\
\hline 10 & Dapat membantu guru dalam pelajaran IPA materi sifat-sifat cahaya & 4 \\
\hline Skor Maksimal & $\mathbf{4 0}$ \\
\hline Skor Total & $\begin{array}{c}\text { Sangat } \\
\text { Valid }\end{array}$ \\
\hline Persentase & $\mathbf{9 0 \%}$ \\
\hline Kategori & \\
\hline
\end{tabular}

\section{Hasil Pengujian Ahli Media}

Media kotak cahaya juga divalidasikan oleh dosen ahli media pembelajaran yaitu Bapak Wanda presentase $86,9 \%$. Berdasarkan tabel 1 dapat dilihat bahwa untuk persentase $100 \%$ adalah valid sehingga petunjuk penggunaan media yang dikembangkan sangat baik digunakan. 
Tabel 4 Hasil Validasi Ahli Media

\begin{tabular}{|c|c|c|c|}
\hline No & \multicolumn{2}{|l|}{ Kriteria } & Skor \\
\hline \multicolumn{4}{|c|}{ Efektifitas } \\
\hline 1 & \multicolumn{2}{|l|}{ Kemudahan siswa dalam memahami materi } & 3 \\
\hline 2 & \multicolumn{2}{|l|}{ Media dapat dengan mudah digunakan oleh guru } & 4 \\
\hline 3 & \multicolumn{2}{|l|}{ Media yang dibuat dapat menjangkau jarak pandang siswa. } & 2 \\
\hline 4 & \multicolumn{2}{|l|}{$\begin{array}{l}\text { Kemampuan media kotak cahaya dalam memberikan kekuatan } \\
\text { mengingat informasi atau materi yang disampaikan }\end{array}$} & 3 \\
\hline 5 & \multicolumn{2}{|l|}{ Kualitas media pembelajaran dalam menyajikan materi sifat cahaya } & 4 \\
\hline 6 & \multicolumn{2}{|l|}{$\begin{array}{l}\text { Tujuan pembelajaran dapat tercapai dengan menggunakan media } \\
\text { kotak cahaya }\end{array}$} & 3 \\
\hline 7 & \multicolumn{2}{|l|}{ Keterlibatan siswa dalam pemanfaatan media pembelajaran } & 3 \\
\hline 8 & \multicolumn{2}{|l|}{ Media dapat digunakan secara individu maupun kelompok } & 3 \\
\hline 9 & \multicolumn{2}{|l|}{ Ketepatan materi dengan media yang dikembangkan } & 4 \\
\hline 10 & \multicolumn{2}{|l|}{$\begin{array}{l}\text { Media pembelajaran Kotak Cahaya memiliki keunggulan dari media } \\
\text { pembelajaran konvensional }\end{array}$} & 4 \\
\hline 11 & \multicolumn{2}{|l|}{ Keamanan media Kotak Cahaya bagi siswa } & 3 \\
\hline \multicolumn{4}{|c|}{ Efisiensi } \\
\hline 12 & \multicolumn{2}{|l|}{ Ketepatan pemilihan bahan-bahan } & 4 \\
\hline 13 & \multicolumn{2}{|l|}{ Penggunaan media kotak cahaya dapat berulang-ulang } & 3 \\
\hline 14 & \multirow{2}{*}{\multicolumn{2}{|c|}{\begin{tabular}{|lll} 
Efisiensi kecepatan pemahaman siswa & terhadap \\
dihasilkan media kotak cahaya & & \\
\end{tabular}}} & 3 \\
\hline & & & \\
\hline 15 & \multicolumn{2}{|l|}{ Mempermudah siswa dalam memahami materi sifat cahaya } & 3 \\
\hline 16 & \multicolumn{2}{|l|}{$\begin{array}{l}\text { Media Kotak Cahaya merupakan media pembelajaran yang kreatif, } \\
\text { dan inovatif }\end{array}$} & 4 \\
\hline \multicolumn{4}{|c|}{ Daya Tarik } \\
\hline 17 & Pemilihan warna pada media kotak cahaya & & 4 \\
\hline 18 & Ketertarikan siswa terhadap media kotak cahaya & & 4 \\
\hline 19 & Daya tarik media kotak cahaya yang disajikan & & 3 \\
\hline 20 & Keserasian antara warna dan bahan-bahan dalam media & & 4 \\
\hline 21 & $\begin{array}{l}\text { Kesesuaian warna yang digunakan dalam media kotak cahaya } \\
\text { terhadap usia siswa }\end{array}$ & & 4 \\
\hline 22 & Kesesuaian background media dengan isi media kotak cahaya & & 4 \\
\hline
\end{tabular}

\section{Hasil Validasi Pengguna}

Media kotak cahaya juga divalidasikan kepada guru kelas 5 SDN Bancaran $4 \mathrm{~B}$ angkalan yang bernama Siska Trisnayanti, S.Pd.SD. Validasi ini bertujuan untuk mengukur tingkat keterterapan media pembelajaran ketika digunakan dalam praktik pembelajaran dikelas dan juga untuk mengetahui tingkat efisiensi media kotak cahaya. Hasil Penilaian pengguna dapat dilihat pada tabel 6. Setelah dilakukan analisis data menggunakan persamaan (1) diperoleh presentase 86,9\%. Berdasarkan tabel 1 dapat dilihat bahwa untuk persentase $87,5 \%$ adalah valid sehingga media yang dikembangkan baik digunakan.

\section{Uji Coba Pengembangan (Develop Mental Testing)}

Menurut Uji coba ini dilakukan untuk mengetahui respon siswa terhadap daya tarik siswa pada media kotak cahaya. Selain itu, untuk mengetahui efektifitas media kotak cahaya pada proses 
Tabel 5 Hasil Validasi ahli bahasa

\begin{tabular}{llc}
\hline No & \multicolumn{1}{c}{ Kriteria } & Skor \\
\hline 1 & Bahasa yang digunakan mudah dipahami & 4 \\
2 & Penulisan kalimat baik dan benar & 4 \\
3 & Kata yang digunakan sesuai dengan EYD & 4 \\
4 & Kalimat yang digunakan sederhana tidak berbelit-belit & 4 \\
5 & Bahasa yang digunakan dapat menyampaikan & 4 \\
$\quad$ informasi kepada pembaca & \\
Total skor yang diperoleh & 20 \\
Skor Maksimal & 20 \\
Presentase & $100 \%$ \\
Kategori & Sangat \\
\hline
\end{tabular}

pembelajaran berlangsung. Uji coba dilakukan pada perorangan, kelompok kecil, kelompok besar. Hasil uji coba dapat dilihat pada tabel 7. Berdasarkan tabel 7 dapat dilihat bahwa hasil uji coba rata-rata presentasenya $>90 \%$, sehingga menurut kriteria media kotak cahaya sangat menarik.

Setelah melalui berbagai validasi yaitu ahli media, ahli materi, validasi pengguna, dan validasi sasaran (uji coba perorangan, uji coba kelompok kecil, dan uji coba kelompok besar) maka didapat produk akhir pengembangan media pembelajaran berupa "Kotak Cahaya". Media kotak cahaya ini juga melewati proses perubahan dan perbaikan (revisi) dari berbagai ahli dan uji coba yang sudah dilakukan. Setelah melalui proses tersebut, maka media Kotak Cahaya ini sudah siap digunakan dan diterapkan dalam pembelajaran IPA dikelas 5 . Media pembelajaran dikatakan layak jika media pembelajaran tersebut efektif, efisien, dan menarik bagi siswa ketika diterapkan dalam pembelajaran.

Efektivitas merupakan tingkat pencapaian siswa yang terukur dengan beberapa aspek seperti kecermatan penguasaan, kecepatan unjuk kerja, tingkat alih belajar, dan tingkat retensi siswa (Subiyantoro,2015). Efektifitas pembelajaran dengan menggunakan media pembelajaran kotak cahaya dapat dilihat dari hasil belajar yang diraih oleh siswa. Persentase yang diperoleh setiap uji coba, baik uji coba perorangan, kelompok kecil, dan kelompok besar memiliki nilai yang sangat tinggi yakni melebihi batas kriteria ketuntasan klasikal yaitu 85\%. (Uno, 2015:211) berpendapat bahwa keefektifan yang diukur dengan persentase berdasarkan tujuan yang telah ditetapkan.

Depdikbud (Trianto,2010:241) menyatakan bahwa setiap siswa dikatakan tuntas belajarnya (ketuntasan individu) jika proporsi jawaban benar siswa $\geq 70$ dan suatu kelas dikatakan tuntas hasil belajarnya (ketuntasan klasikal) jika dalam kelas tersebut terdapat $\geq 85 \%$ yang telah tuntas belajarnya. Sehingga dari keadaan tersebut dapat disimpulkan bahwa media kotak cahaya sanagatlah efektif digunakan dalam pembelajaran IPA khususnya pada materi sifat-sifat cahaya. Media kotak cahaya mampu meningkatkan hasil belajar siswa, sehingga efektif digunakan dalam kegiatan pembelajaran siswa(Subiyantoro,2015).

Efisiensi pembelajaran adalah rasio antara keefektifan dan jumlah waktu yang digunakan siswa dan atau jumlah biaya pembelajaran yang digunakan Dikatakan efisiensi apabila keberhasilan pembelajaran yang dicapai tidak memerlukan waktu dan biaya yang besar (Uno, 2015:211). Media kotak cahaya juga efisien untuk digunakan, karena mempermudah menyampaikan materi sifat-sifat cahaya. Selain itu juga menghemat waktu dalam mengajarkan materi sifat-sifat cahaya. Siswa juga dapat belajar sendiri tanpa adanya guru 
Tabel 6. Hasil angket pengguna

\begin{tabular}{|l|l|c|}
\hline No & \multicolumn{1}{|c|}{ Kriteria } & Skor \\
\hline 1 & $\begin{array}{l}\text { Kesesuaian waktu yang tersedia dalam pembelajaran dengan } \\
\text { kemudahan pengoperasian media }\end{array}$ & 3 \\
\hline 2 & $\begin{array}{l}\text { Kemampuan media sebagai alat bantu pencapaian indikator/tujuan } \\
\text { pembelajaran }\end{array}$ & 3 \\
\hline 3 & $\begin{array}{l}\text { Ketertarikan siswa ketika belajar dengan memanfaatkan media } \\
\text { yang dikembangkan }\end{array}$ & 4 \\
\hline 4 & Kemampuan media menciptakan rasa senang & 4 \\
\hline 5 & Kemampuan media untuk dapat digunakan secara berulang-ulang & 4 \\
\hline 6 & Kemampuan media dalam menciptakan motivasi belajar siswa & 4 \\
\hline 7 & Kemampuan media membantu siswa memahami informasi & 3 \\
\hline 8 & Kemampuan media dalam memicu kreativitas siswa & 4 \\
\hline 9 & $\begin{array}{l}\text { Kemampuan media untuk mengaktifkan siswa dalam membangun } \\
\text { pengetahuan sendiri }\end{array}$ & 3 \\
\hline 10 & Kesesuaian media dengan dunia siswa yang sedang diajar & $\mathbf{4 0}$ \\
\hline Skor Maksimal
\end{tabular}

Tabel 7. Hasil uji coba pengembangan

\begin{tabular}{|l|l|l|l|l|}
\hline No & Uji Coba & $\begin{array}{l}\text { Jumlah } \\
\text { siswa }\end{array}$ & $\begin{array}{l}\text { Rata-rata } \\
\text { Presentase }\end{array}$ & Kriteria \\
\hline 1. & Perorangan & 3 & 98,3 & Sangat menarik \\
\hline 2. & Kelompok kecil & 7 & 94,6 & Sangat menarik \\
\hline 3. & Kelompok Besar & 22 & 96,6 & Sangat menarik \\
\hline
\end{tabular}

Tabel 8. Presentase Ketuntasan siswa

\begin{tabular}{|l|l|l|l|}
\hline \multirow{2}{*}{$\begin{array}{l}\text { Presentase } \\
\text { Ketuntasan }\end{array}$} & Perorangan & Kelompok kecil & Kelompok Besar \\
\cline { 2 - 4 } & $100 \%$ & $100 \%$ & $95,4 \%$ \\
\hline
\end{tabular}

jika menggunakan media kotak cahaya karena didalam media kotak cahaya terdapat buku panduan bagi siswa dan guru. Sehingga dapat disimpulkan bahwa media kotak cahaya sangat efektif dan efisien digunakan pada pembelajaran IPA kelas 5 sekolah dasar. Hal ini sesuai dari hasil validasi pengguna yang dilakukan oleh guru yaitu sebesar $87,5 \%$. Sehingga dapat disimpulkan bahwa media kotak cahaya sangat efisien untuk digunakan dalam pembelajaran. Sedangkan kemenarikan pembelajaran merupakan tingkat ketertarikan siswa terhadap pembelajaran yang dapat diukur dengan mengamati kecenderungan siswa untuk terus belajar (Subiyantoro,2015).
Kemenarikan siswa pada media kotak cahaya dapat dilihat dari hasil persentase lembar kuisioner yang disebarkan. Dalam media tersebut dibahas mengenai kesukaan mereka dalam belajar dengan media kotak cahaya. Hasil uji coba yang dilakukan diperoleh rata-rata presentase sebesar 98,3\% untuk uji perorangan, 94,6\% uji kelompok kecil, 96,6\% uji kelompok besar.

Uno (2015:211) berpendapat bahwa menarik yang diukur dengan semakin tinggi keefektifan pembelajaran, maka makin tertarik siswa pada pelajaran tersebut. Dapat dikatakan jika semakin tinggi hasil belajar siswa maka media pembelajaran yang digunakan 
semakin efektif dan menarik untuk siswa. Hal ini sesuai dengan hasil ketuntasan hasil belajar siswa yaitu pada tabel 8 .

\section{SIMPULAN}

Berdasarkan hasil dan pembahasan penelitian ini didapat kesimpulan bahwa (1) telah dibuat media kotak cahaya dengan pengembangan model 4D materi sifat-sifat cahaya, (2) media yang telah dikembangkan telah memenuhi syarat kelayakan melalui pengujian ahli materi dengan persentase sebesar $90 \%$ termasuk dalam kriteria sangat baik digunakan, pengujian ahli

\section{DAFTAR PUSTAKA}

Arsyad, Azhar. (2007). Media Pembelajaran. Jakarta : PT Raja Grafindo Pusada 2013. Media Pembelajaran. Jakarta : Raja Grafindo Persada

Rustaman, Nuryani, dkk. 2010. Materi dan Pembelajaran IPA SD. Jakarta : Universitas Terbuka

Sanjaya, Wina. 2011. Strategi Pembelajaran. Jakarta : PRENADAMEDIA GROUP

Subiyantoro. 2015. Efektifitas, Efisiensi, dan Daya Tarik. (Online): (https://eprints.uns.ac.id/18041/2 /2.BAB_I_Pendahuluan.pdf. di akses 17 Juni 2016 (04.00)) media dengan presentase sebesar $86,9 \%$ termasuk dalam kriteria baik digunakan, pengujian ahli bahasa sebesar $100 \%$ untuk petunjuk penggunaan media, dan pengujian pengguna dengan presentase sebesar $87,5 \%$, sedangkan untuk uji coba media kotak cahaya diperoleh untuk uji perorangan sebesar $98,3 \%$, uji kelompok kecil sebesar $94,6 \%$ dan uji kelompok besar sebesar 96,6\%. Maka dari hasil pengujian media kotak cahaya yang dikembangkan sengat baik digunakan dalam proses pembelajaran.

Sudjana, Nana \& Ahmad Rivai. (2011). Media Pengajaran. Bandung: Sinar Baru Algensindo.

Thiagarajan,S. Semmel, D.S Semmel, M.I. $\quad 1974 . \quad$ Instructional Development for Training

Teacher of Exceptional Children: A Sourcebook. Blomongton: indiana University

Uno, Hamzah. Dkk.2015. Belajar Dengan Pendekatan PAILKEM : Pembelajaran Aktif,

Inovatif, Lingkungan, Kreatif, Efektif, Menarik. Jakarta: PT Bumi Aksara 